\title{
UVEAL MELANOMA: AN OVERVIEW OF MANAGEMENT AND PROGNOSIS
}

\author{
SNJEŽANA KAŠTELAN ${ }^{1}$, ANTONELA GVEROVIĆ ANTUNICA ${ }^{2}$, \\ LIDIJA BEKETIĆ ORESKOVIĆ ${ }^{3}$, BORIS KASUN ${ }^{4}$ and KORALJKA HAT ${ }^{5}$ \\ ${ }^{1}$ Department of Ophthalmology, University Hospital Dubrava, Zagreb, Croatia; \\ ${ }^{2}$ Department of Ophthalmology, General Hospital Dubrovnik, Dubrovnik, Croatia; \\ ${ }^{3}$ Department of Clinical Oncology, School of Medicine, University of Zagreb, \\ and Division of Radiotherapy and Medical Oncology, University Hospital for Tumors, \\ Sestre milosrdnice University Hospital Center, Zagreb, Croatia; \\ ${ }^{4}$ Special Hospital for Medical Rehabilitation Stubičke Toplice, Stubičke Toplice, Croatia; \\ ${ }^{5}$ Department of Maxillofacial Surgery, University Hospital Dubrava, Zagreb, Croatia.
}

\begin{abstract}
Summary
Uveal melanoma represents $5 \%$ of all melanomas and the eye is the second most common site for primary melanoma after the skin. Delays or failure to make an accurate and early diagnosis may have fatal consequences. Advances in the diagnosis and local and systemic treatment of uveal melanoma in recent times have caused a shift from enucleation to eye-conserving treatment modalities. Currently, radiotherapy is the most commonly used therapeutic option, which can include: brachytherapy- radioactive plaque, as the most frequently used form, than stereotactic external beam radiotherapyradiosurgery as well as proton therapy, as a form of charged-particle radiotherapy. However, surgery as an inevitable therapeutic option has to be performed in some cases. In the treatment of primary tumor, local treatment methods are effective in preventing local recurrence in over $95 \%$ of cases. However, metastatic disease develops in up to $50 \%$ of patients, with liver metastases, as the most common. At this stage of the disease there is a poor survival rate of the patients (4-15 months) and this has remained relatively unchanged over the past decades. Although potential therapeutic targets have been identified, there is no currently effective treatment of metastatic disease. Pending clinical trials involving chemotherapeutic, immunotherapeutic and molecularly targeted agents offer hope for successful tumor control and vision preservation as well as metastases prevention and improvement of overall patient survival.
\end{abstract}

KEY WORDS: uveal melanoma, therapy, systemic metastasis, prognosis

\section{MELANOM SREDNJE OČNE OVOJNICE: LIJEČENJE I PROGNOZA}

\section{Sažetak}

Melanom srednje očne ovojnice predstavlja 5\% svih melanoma. Oko je, nakon kože, drugo primarno sijelo melanoma. Kasna ili kriva dijagnoza može imati ozbiljne posljedice. Napredak u dijagnostici te lokalnom i sustavnom liječenju doveo je do češće primjene metoda kojima je cilj očuvati oko i vid. Radioterapija, kao danas najčešći oblik liječenja, može biti primjenjena kao: brahiterapija - radioaktivni plak, najčešće korištena metoda, potom stereotaktička radioterapija vanjskim zračenjem, tzv. radiokirurgija, kao i čestično zračenje, npr. protonska radioterapija. Enukleacija oka se, kao neizbježni oblik liječenja, ipak mora primijeniti u određenim slučajevima. Kod primarnog tumora, lokalne metode liječenja učinkovite su u sprječavanju lokalnog recidiva u više od 95\% slučajeva. Međutim, metastatska bolest razvija se u oko 50\% bolesnika, a najčešće sijelo presadnica je jetra. Stopa preživljenja bolesnika s presadnicama je 4-15 mjeseci i gotovo je nepromijenjena tije- 
kom posljednjih desetljeća. Iako se otkrivaju potencijalne ciljne mete sistemske terapije, ne postoji još djelotvorna metoda liječenja metastatske bolesti. U tijeku su klinička ispitivanja liječenja kemoterapijom i imunoterapijom koja otvaraju mogućnosti uspješne kontrole i liječenja tumora uz očuvanja vida bolesnika te prevencije razvoja metastatske bolesti i povećanja stope preživljenja bolesnika.

KLJUČNE RIJEČI: melanom srednje očne ovojnice, liječenje, sustavne metastaze, prognoza

\section{INTRODUCTION}

Uveal melanoma (UM) is a rare disease accounting for $0.1 \%$ of all cancer deaths. It can occur in all parts of the uvea: choroid (90\%) (Figure 1.), ciliary body $(7 \%)$ and iris $(2 \%)$. This disease represents $80 \%$ of ocular and $5 \%$ of all melanomas (1-8). Over the years, with advances in treatment strategies, there is an improvement in local tumor control. However the median survival rate of patients remains practically unchanged $(2-4,7,8)$. Although rare, uveal melanoma is the most common primary intraocular malignant tumor in adults, with an annual incidence of five to six cases per million in white populations in the United States and Europe $(1,2)$. In Europe incidence of uveal melanoma is higher in northern (over 8 per million) compared to southern countries (less than 2 per million) indicating an association with geographic latitude (6). Known predisposing factors for this tumor are ethnicity $(7)$, age $(6,7)$, light eye colour, fair skin, the inability to tan, cutaneous, iris and choroidal nevus, ocular or oculodermal melanocytosis and familial uveal melanoma $(2,4)$.

Uveal melanoma has a high predisposition to metastasize mostly in the liver (89\%), lungs (29\%),

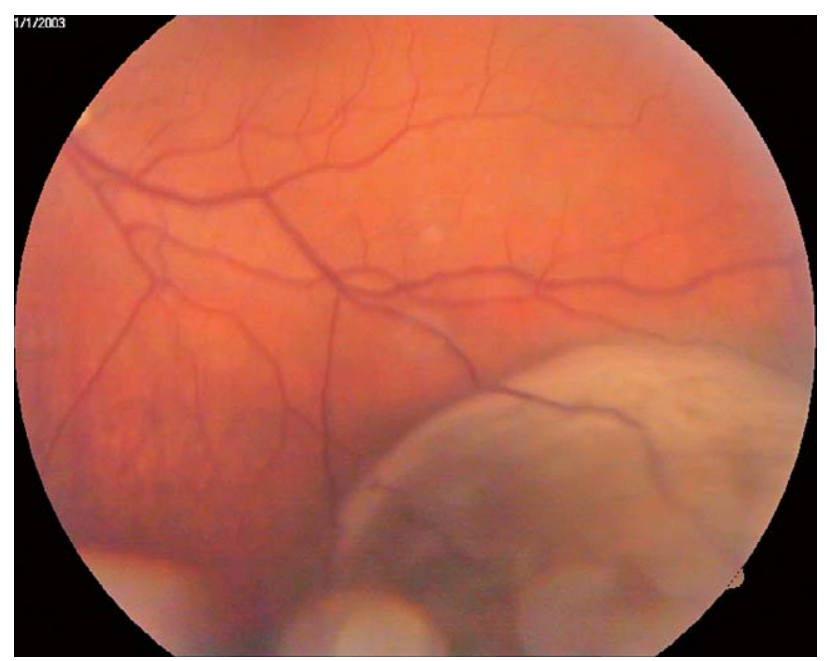

Figure 1. Choroidal melanoma and bones $(17 \%)$ resulting in a high mortality rate (7,9-13). Approximately, in 50\% of patients with uveal melanoma metastasis occurs within 10 years of diagnosis, in spite of the treatment method $(7,10-13)$. Survival rate after the onset of metastasis 4 - 15 months $(9,11)$ with a slightly better prognosis in those patients receiving treatment for metastasis $(9,14,15)$.

Various clinical, histopathological, and cytogenetic features of uveal melanoma can identify patients with a high propensity for developing metastasis and potential benefit of suitable adjuvant and adjunctive treatments (Table 1). Unfortunately, systemic chemotherapy is usually ineffective in metastatic uveal melanoma resulting in a response rate ranging from 5\% to $15 \%$ (14). Despite numerous therapies being developed, the 5-year survival rate of patients with uveal melanoma has not improved over the past decades $(13,14)$. However, participating in available clinical trials with immunotherapy and targeted therapy remains for now the best treatment option for these patients (12-14).

Table 1.

RISK FACTORS FOR METASTASIS OF UVEAL MELANOMA

\begin{tabular}{|l|l|}
\hline Risk factors & $\begin{array}{l}\text { increasing age, large tumor size, tumor } \\
\text { growth, greatest basal dimension, } \\
\text { oculodermal melanocytosis, ciliary body } \\
\text { tumor, dark pigmented tumor, } \\
\text { subretinal fluid or intraocular haemorrhage, } \\
\text { extraocular extension }\end{array}$ \\
\hline Histopathological & $\begin{array}{l}\text { epitheloid cell type, anterior location, diffuse } \\
\text { growth pattern, mitotic figures, } \\
\text { pigmentation, expressed necrosis and } \\
\text { inflammatory components }\end{array}$ \\
\hline Molecular & $\begin{array}{l}\text { Tyrosinase m-RNA, Vascular endothelial } \\
\text { growth factor, } \\
\text { Hepatocyte growth factor Insuline-like } \\
\text { growth factor-1 }\end{array}$ \\
\hline Cytological & $\begin{array}{l}\text { Chromosome alternations (monosomy 3, } \\
\text { gains in chromosome 8) } \\
\text { Gene mutations (mutations in GNAQ, } \\
\text { mutations in GNA11) }\end{array}$ \\
\hline
\end{tabular}




\section{Management}

The currently accepted form of uveal melanoma management requires accurate evaluation of all prognostic factors. Applied therapy needs to be individualized according to various factors, such as patient's age, tumor size and location, general health, status of the other eye as well as patients' preferences and expectations. The treatment modality also includes assessment for metastasis risk, the planning of adjuvant therapies, post-treatment monitoring and control of possible recurrence and potential treatment-related ocular side effects. However, none of the offered modalities have improved patients' survival (16-18).

Eye-conserving therapies and enucleation are possible treatment alternatives for uveal melanoma patients without systemic disease. Studies have shown that despite developments in various treatment procedures over the last 30 years, sur- vival rates have remained constant indicating that successful local treatment of the eye does not influence survival. Therefore, it is essential to identify patients with higher risk of metastasis and in addition to local treatment initiate appropriate adjuvant therapies. At the time of initial ocular presentation the occurrence of distant metastases is rare, finding in less than $5 \%$ of cases. In its presence, local eye therapy may be delayed in favour of systemic treatment depending on eye related symptoms (17-21).

\section{Primary treatment}

In the case of small, pigmented choroidal tumor monitoring the lesion is usually adopted until findings on colour fundus photography indicate growth. Since it is not possible to recognise the point at which tumors will metastase, the metastatic spread may occur if treatment is delayed.

Table 2.

THERAPEUTIC MODALITIES FOR UVEAL MELANOMA

\begin{tabular}{|c|c|c|c|}
\hline Treatment & & Indication & Complication \\
\hline \multirow[t]{3}{*}{ Radiotherapy } & $\begin{array}{l}\text { Brachytherapy } \\
\text { (episcleral radioactive } \\
\text { plaque) }\end{array}$ & $\begin{array}{l}\text { Small/medium/large uveal melanoma } \\
\leq 18 \mathrm{~mm} \text { in basal diameter } \\
\leq 12 \mathrm{~mm} \text { in thickens }\end{array}$ & $\begin{array}{l}\text { Loss of vision } \\
\text { Tumor recurrence } \\
\text { Radiation related complication (Retinopathy, } \\
\text { optic neuropathy, NVG, cataract) }\end{array}$ \\
\hline & $\begin{array}{l}\text { Proton beam } \\
\text { radiotherapy }\end{array}$ & $\begin{array}{l}\text { Medium to large uveal melanoma which cannot } \\
\text { be treated with brachytherapy or resection }\end{array}$ & $\begin{array}{l}\text { Loss of vision } \\
\text { Tumor recurrence } \\
\text { Neovascular glaucoma }\end{array}$ \\
\hline & $\begin{array}{l}\text { Stereotactic } \\
\text { radiosurgery }\end{array}$ & $\begin{array}{l}\text { Juxta-papillary uveal melanoma, } \\
\text { patient unsuitable for brachytherapy or } \\
\text { resection }\end{array}$ & $\begin{array}{l}\text { Loss of vision } \\
\text { Tumor recurrence } \\
\text { Radiation related complication } \\
\text { (Retinopathy, optic neuropathy, NVG, cataract) }\end{array}$ \\
\hline \multirow[t]{2}{*}{ Phototherapy } & $\begin{array}{l}\text { Transpupillary } \\
\text { thermotherapy }\end{array}$ & $\begin{array}{l}\text { Adjuvant therapy } \\
\text { Local recurrence }\end{array}$ & $\begin{array}{l}\text { Loss of vision } \\
\text { Extraocular tumor recurrence }\end{array}$ \\
\hline & Photodinamic therapy & Small melanoma & Tumor recurrence \\
\hline \multirow[t]{4}{*}{ Surgery } & $\begin{array}{l}\text { Exoresection } \\
+/- \text { brachytherapy }\end{array}$ & $\begin{array}{l}\text { Small to medium to large melanoma with a } \\
\text { narrow basal diameter }\end{array}$ & $\begin{array}{l}\text { Retinal detachment } \\
\text { Loss of vision } \\
\text { Loss of the eye } \\
\text { Tumor recurrence } \\
\text { Risk of orbital dissemination of the tumor }\end{array}$ \\
\hline & $\begin{array}{l}\text { Endoresection } \\
+/- \text { radiotherapy }\end{array}$ & $\begin{array}{l}\text { Small to medium sized uveal melanoma } \\
\text { Toxic tumor syndrome post PBR }\end{array}$ & $\begin{array}{l}\text { Transient intraocular haemorrhage } \\
\text { Tumor seeding - rarely }\end{array}$ \\
\hline & Enucleatio & $\begin{array}{l}\text { Large uveal melanoma (in patients with one } \\
\text { seeing eye) } \\
\text { Melanoma associated with NVG +/- extensive } \\
\text { retinal detachment } \\
\text { Invasion of the optic disc }\end{array}$ & $\begin{array}{l}\text { Socket related complications } \\
\text { Orbital recurrence }\end{array}$ \\
\hline & Exenteratio & $\begin{array}{l}\text { Large extraocular extension of uveal melanoma } \\
\text { Orbital recurrence after enucleation }\end{array}$ & Orbital recurrence \\
\hline
\end{tabular}

NVG - Neovascular glaucoma

PBR - Proton beam radiotherapy 
Conversely, small tumors should be evaluated considering that $30-40 \%$ of small melanomas are situated close to the optic disc and macula and treatment of all suspicious choroidal tumors in some cases could result in avoidable visual impairment $(2,22,23)$. Treatment of the primary tumor is guided by tumor size, lesion location, general health of the patient, visual acuity at presentation and patient preference and expectations. In management of uveal melanoma the assessment of prognostic factors should also be included. The main treatment options for uveal melanoma are eye-conserving therapies or enucleation. Studies have demonstrated that despite developments in treatment methods and the increasing tendency toward eye-sparing therapies, survival rates have remained constant $(2-4,7,8,20)$ (Table 2$)$.

\section{Radiotherapy}

Currently the most common treatment for uveal melanoma is radiotherapy which can be administered in the form of radioactive plaque (brachytherapy), or with external beam radiotherapy using stereotactic methods, radiosurgery (SRT), or radiotherapy with charged praticles such as protones $(2-4,20)$.

Brachytherapy is the direct irradiation of a tumor via the application of a radioactive source (radioisotope) to the tumor surface or interior (2) (Figure 2). This type of treatment is applicable when melanoma is $\leq 18 \mathrm{~mm}$ in diameter and $\leq 12$ $\mathrm{mm}$ in thickness (19). The two most common radioisotopes used in the plaques are iodine-125 $\left({ }^{125} \mathrm{I}\right)$ and ruthenium-106 $\left({ }^{106} \mathrm{Ru}\right)(19,24) .{ }^{125} \mathrm{I}$ plaques emit gamma radiation, which has a deeper penetration than the beta-emitting ${ }^{106} \mathrm{Ru}$ but increased toxicity to surrounding healthy tissue $(8,24)$. The lower penetration depth of ${ }^{106} \mathrm{Ru}$ makes it unsuitable for thick tumors and is generally restricted to those that are less than $6 \mathrm{~mm}$ in thickness $(8,25)$. Regular ophthalmologic examinations should be performed following plaque brachytherapy to assess for radiation-induced damage, including radiation retinopathy, papillopathy, exudative retinal detachment and cataract which can develop 2 to 5 years following initial treatment (8).

External beam radiotherapy can be performed using different stereotactic methods or charged particles such as proton and helium ion beams. This modality can be used to treat tumors

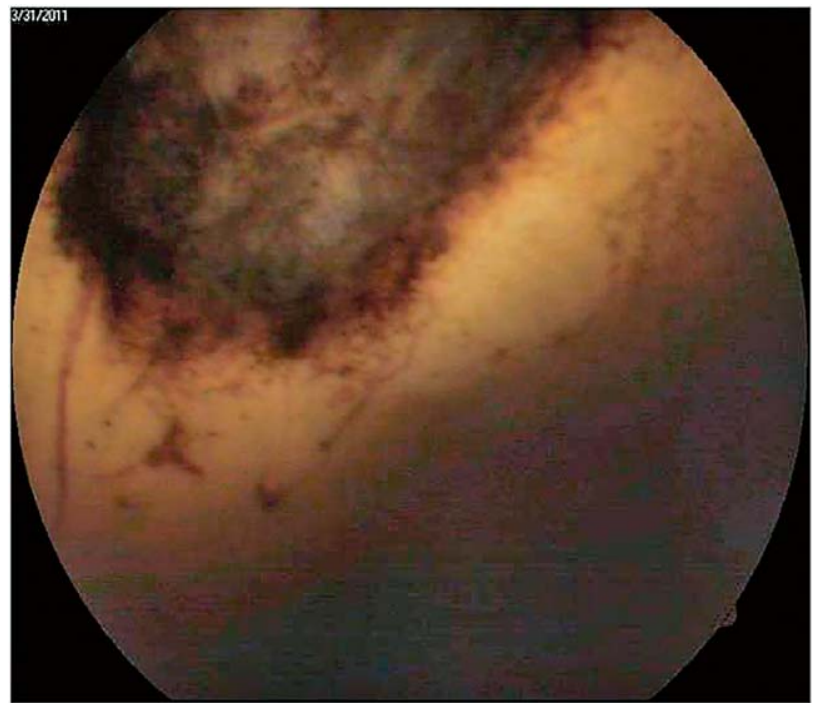

Figure 2. Choroidal melanoma - finding 10 years after brachytherapy

up to $14 \mathrm{~mm}$ thick with a basal diameter up to 28 $\mathrm{mm}(2,8,26)$.

Proton beam therapy is a form of radiation treatment which emits homogenous dose of radiation to the entire tumor while limiting irradiation of surrounding tissues $(2,27)$. Theoretically, all uveal melanomas could be treated by proton beam therapy but for large melanomas the visual prognosis and eye conservation rates remain low $(27,28)$. The first choice of treatment for large tumors located in the superotemporal quadrant should be radioactive plaque radiotherapy in order to spare the lacrimal glands. Possible complications of proton beam therapy are loss of eyelashes, retinal detachment, glaucoma, dry eye, cataract, optic neuropathy and maculopathy.

Transpupillary thermotherapy (TTT) was used as an adjuvant therapy when the tumor was close to the macula or to decrease the likelihood of neovascular glaucoma and recurrence was not observed in these patients $(2,19,28)$.

The devices used in stereotactic radiotherapy (SRT) are the gamma knife, linear accelerator and the cyber knife. Ocular immobilization is required during these treatments. This can be achieved with retrobulbar anaesthesia or vacuum-assisted immobilization frame for the gamma knife and the cameras used to monitor eye movements for the linear accelerator (28). The local tumor control, 
visual acuity and survival rate with this method is similar to the proton beam therapy $(2,19)$.

\section{Photocoagulation, transpupillary thermal therapy and photodynamic therapy}

Photocoagulation was frequently used in the past to treat small choroidal melanoma. Today, small tumors less than $3 \mathrm{~mm}$ in thickness and located more than $3 \mathrm{~mm}$ from the fovea are treated with TTT $(2,29)$ (Figure 3). Patients undergoing TTT alone for uveal melanoma should be selected carefully keeping in mind that although visual prognosis is good, there remains the long-term possibility of recurrence with high metastatic risk (2). Several studies have explored the potential role of TTT in combination with brachytherapy ("sandwich therapy") and proton beam therapy, with mixed results $(8,30)$. TTT has also been used as an adjuvant therapy, although no improved local control was observed in ${ }^{125}$ I-treated juxtapapillary uveal melanoma (8).

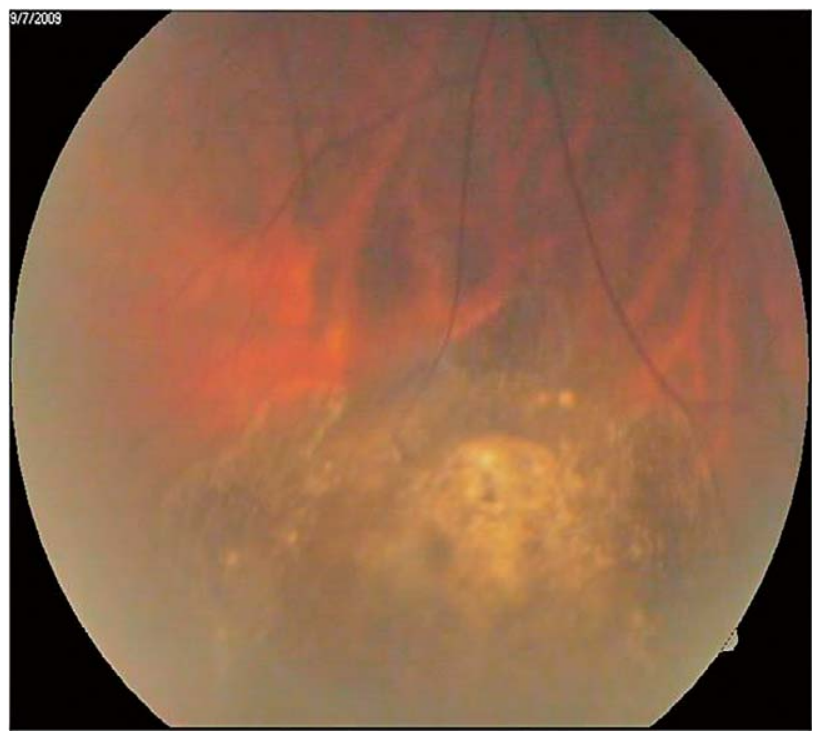

Figure 3. Choroidal melanoma - finding after transpupillary thermotherapy

Photodynamic therapy involves injection of a light-sensitive compound, such as benzoporphyrin or verteporfin, followed by exposure to a specific wavelength of light in order to release damaging free radicals that can destroy neighbouring vascular endothelial cells. The long-term local control and disease-free survival benefit of this technique are still under investigation (19).

\section{Complications of radiotherapy}

Complications of radiation treatment of uveal melanoma can be radiation retinopathy and radiation induced optic neuropathy.

Radiation retinopathy is a slowly progressive disease caused by radiation-induced endothelial damage and capillary occlusion which results in retinal haemorrhage, macular oedema, vascular sheathing, microaneurysms, retinal exudation, telangiectasias, retinal pigment epithelial atrophy and cotton wool spots. Retinopathy occurrence is dependent on the total radiotherapy dose received and the area of the retina irradiated. Ischemic retinopathy can often progress to proliferative retinopathy with possible vitreous haemorrhage $(2,3,31)$. Treatment options include panretinal or focal laser photocoagulation, photodynamic therapy, intravitreal or periocular triamcinolone injection, oral pentoxifylline, hyperbaric oxygen, intravitreal anti-vascular endothelial growth factor (anti-VEGF) and silicone application prior to brachytherapy $(2,3,31)$.

Radiation-induced optic neuropathyis characterized by optic disc haemorrhage, disc pallor, and/or disc oedema. It is manifested with sudden, painless, unilateral vision loss starting as early as 3 months or up to 8 years after radiation exposure $(2,3,31)$. There is no proven treatment of radiation optic neuropathy; mixed results have been reported for systemic and intravitreal corticosteroids or intravitreal anti-VEGF therapy, hyperbaric oxygen and anticoagulation therapy $(2,3,31)$.

\section{Surgery - enucleation, exenteration, local resection}

Although enucleation was formerly the most common treatment choice, it is currently reserved for cases with the worst visual prognosis, such as patients with large uveal melanoma (tumoral thickness greater than $8 \mathrm{~mm}$ ), choroidal melanoma surrounding the optic nerve or presenting with retinal detachment or vitreous haemorrhage. There is no consensus on the maximum tumor thickness that can be treated by radiotherapy (2$4,8,19)$. In response to the results of Collaborative ocular melanoma study (COMS) in which enucleation did not provide any survival benefit over brachytherapy in medium-sized choroidal tumors, vision-sparing treatments become the preferred choice (10). Furthermore pre-enucleation 
radiotherapy did not seem to improve survival in patients with large choroidal melanomas (32). In eyes with large areas of extraocular extension or those with orbital tumor extension orbital exenteration is performed $(2,14,16)$.

Local resection is an alternative treatment choice for choroidal melanoma patients which spares the eye and allows a detailed histopathologic and cytogenetic analysis. The procedure is more preferred in cases of iris and ciliary body melanoma. It can be performed transretinaly (endoresection) or transscleraly (exoresection) with vitreous haemorrhage and retinal detachments being possible complications. Radiotherapy is recommended as an adjuvant to exoresection to prevent tumor recurrence although its preventative application before endoresection is still controversial $(2,33)$.

\section{Systemic metastasis}

At the time of diagnosis, less than $5 \%$ of patients with uveal melanoma have detectable metastatic disease. However, with the tumor progression nearly half of the patients will develop metastases $(2-4,20,21)$ (Table 3). Once metastasis has occurred survival is poor due to the lack of effective systemic treatment. Uveal melanoma disseminates hematogenously, with the most common metastatic sites in liver, lung and bones $(34,35)$, but metastases in the brain, skin and other sites of the body can be also found (43). Patients with liver metastases survive for an average of 4-6 months with a 1-year survival rate of $10-15 \%$. Reported survival time for patients with other metastases is 19-28 months $(2,4,35)$ (Table 4$)$.

There are no definitive guidelines regarding screening tests for systemic metastasis in uveal melanoma however clinical examination for the presence of subcutaneous nodules and organomegaly is the basis. Since the most frequent site of metastasis is the liver, examination should include liver function tests and complementary radiography methods particularly ultrasonography (USG) $(2-4,21,36)$. The most sensitive method for liver imaging is contrast and magnetic resonance imaging (MRI). Computed tomography (CT) is highly sensitive yet its ability to discriminate from benign lesions is limited. Brain imaging and bone scan are required only in the presence of related symptoms $(2,37)$.
Table 3.

SYSTEMIC METASTASIS OF UVEAL MELANOMA IN RELATIONSHIP TO THE SITE OF THE PRIMARY TUMOR

\begin{tabular}{|l|l|l|l|}
\hline Site of primary tumor & \multicolumn{4}{|l|}{ Systemic metastasis incidence (\%) } \\
\hline & 3 years & 5 years & 10 years \\
\hline Iris & 0.5 & 4 & 7 \\
\hline Ciliary body & 12 & 19 & 33 \\
\hline Choroidal & 8 & 15 & 25 \\
\hline
\end{tabular}

Table 4.

SITES OF SYSTEMIC METASTASIS OF UVEAL MELANOMA

\begin{tabular}{|l|l|l|}
\hline $\begin{array}{l}\text { Site of systemic } \\
\text { metastasis }\end{array}$ & Incidence $(\%)$ & $\begin{array}{l}\text { Mean survival time } \\
\text { (months) }\end{array}$ \\
\hline Liver & 89 & $4-6$ \\
\hline Lung & 29 & $19-28$ \\
\hline Bones & 17 & $19-28$ \\
\hline Skin & 12 & $19-28$ \\
\hline Lymph nodes & 11 & $19-28$ \\
\hline
\end{tabular}

Numerous clinical and histopathological features have been investigated in order to predict prognosis of uveal melanoma. Factors associated with poor outcome include advanced patient age at time of diagnosis, large tumor size, extrascleral extension of the tumor, involvement of the ciliary body and presence of subretinal fluid or intraocular hemorrhage. Certain pathologic features including epithelioid cytology, increased mitotic activity, extracellular matrix patterns, immune cell infiltration and incomplete local control after primary tumor treatment are also connected with poor prognosis $(2-4,8,11,38)$.

\section{Adjuvant therapy}

Local treatment of a primary uveal tumor is effective in preventing local recurrence in over $95 \%$ of cases; nevertheless nearly $50 \%$ of patients will develop metastatic disease in a median time of 5 years. In fact, circulating uveal tumor cells have been detected at diagnosis in patients with no detectable metastases $(8,39)$. Metastatic uveal melanoma is resistant to treatment with no evidence that current treatment can extend survival. The efficacy of systemic treatment could be improved with adjuvant therapies that target micrometastases and the identification of patients at high risk is very important. There is currently no standard therapy for metastatic uveal melanoma with a broad range of systemic treatment options 
including chemotherapy, immunotherapy, hormone, biologic and targeted therapy. Hepatic-directed treatments have also been developed; however intra-arterial hepatic administration result in better tumor response than systemic therapy without increasing survival in the long term $(8,25,40)$.

\section{Treatment of metastatic uveal melanoma}

\section{Systemic chemotherapy}

Systemic chemotherapeutic protocols in uveal melanoma have been adopted from those used in cutaneous melanoma however no conventional chemotherapeutic agent has been found to extend survival in patients with metastatic disease. Response rates for systemic chemotherapy of metastatic uveal melanoma range from $0 \%$ to $15 \%$ (2$4,8,19)$.

\section{Systemic immunotherapy}

Recent advances in immunotherapy have considerably improved survival of patients with metastatic cutaneous melanoma although the clinical benefit in uveal melanoma is more limited. A possible explanation is that uveal melanoma is typified by a low mutational burden, since UV radiation-induced DNA damage does not play a significant role in tumor pathogenesis $(8,41)$. Another possible explanation arises from "immune privilege" of the eye, meaning an adaptation to reduce immune-mediated injury in organs that have limited capacity for regeneration such as the eye and brain. Studies have shown that aqueous humour contains a number of anti-inflammatory and immunosuppressive cytokines $(8,42)$ which at least partially could be an explanation for this immunological adaptation.

\section{Molecularly targeted therapy}

As a result of increased understanding of the oncogenic pathways in uveal melanoma a number of potential therapeutic targets have been recognized. Since the mitogen-activated protein kinase (MAPK) pathway is activated in the majority of uveal melanoma cases, inhibitors of downstream effectors, for instance mitogen activated kinase (MEK) and protein kinase C (PKC) are presently undergoing clinical investigation. The common $B R A F$ mutations in cutaneous melanoma are pres- ent in less than $1 \%$ of uveal melanoma tumors. Thus BRAF inhibitors become unsuitable for treating uveal melanoma even though they have proven to be beneficial in the treatment of the cutaneous tumor type (8).

\section{Liver-directed therapies}

In certain cases, surgical removal of metastatic nodules can offer long-term survival benefit. Alternative approaches include radiofrequency ablation, cryotherapy and stereotactic radiotherapy. Other liver-directed therapies take advantage of the dual blood supply in the liver which allows more direct treatment of the metastases via the hepatic artery. Hepatic artery branches vascularize the melanoma, whereas the portal circulation delivers the majority of blood to the normal liver tissue. Intrahepatic therapeutic methods consist of bland embolization, intra-arterial administration of chemotherapies, isolated hepatic perfusion, intra-arterial hepatic chemo embolization, radioembolisation and immune embolization $(8,19,43)$ (Table 5).

\section{Prognostic and predictive factors}

The patients treated with plaque brachytherapy, proton beam radiotherapy or stereotactic radiotherapy should be closely monitored for tumor regression during the first two years after primary treatment (16). Further follow up is dependent on the tumor response to brachytherapy and possible radiotherapy complications.

Regular screening is recommended for patients at high risk of relapse. This screening includes hepatic imaging (CT/MRI) and liver function tests conducted in a three to six month interval for the first five years followed by six to twelve month intervals thereafter. Although surveillance regimens differ, some studies suggest lactate dehydrogenase (LDH) and gamma-glutamyl transferase (GGT) as the most sensitive liver function tests for uveal melanoma which are most often elevated with advanced hepatic involvement $(17,44)$.

\section{Future Directions}

Advancement of the understanding of biological behaviour of the uveal melanoma is central to the development of new therapeutic strategies. Programs addressing genomic alterations of pri- 
Table 5 .

LIVER DIRECTED THERAPY METHODS USED IN THE TREATMENT OF UVEAL MELANOMA METASTASIS

\begin{tabular}{|c|c|c|}
\hline Procedures & Comments & Outcome \\
\hline Hepatic metastasectomy & $\begin{array}{l}\text { - Surgical resection } \\
\text { - Limited indication (good physical condition } \\
\text { for general anesthesia) } \\
\text { - Small number of potential candidates } \\
\text { (<10\% patients with liver uveal metastasis) }\end{array}$ & $\begin{array}{l}\text { - Median OS time }>12 \text { months } \\
\text { - Has not enhanced survival in comparison to } \\
\text { systemic therapy } \\
\text { - Common local relapse }\end{array}$ \\
\hline Radiofrequency ablation & $\begin{array}{l}\text { - Method that spares the hepatic parenchyma } \\
\text { - Anesthesia and extensive surgical procedure } \\
\text { are avoided } \\
\text { - Minimal morbidity and mortality }\end{array}$ & $\begin{array}{l}\text { - No difference in survival time and DFS } \\
\text { in regard to surgical resection }\end{array}$ \\
\hline $\begin{array}{l}\text { Hepatic arterial infusion of } \\
\text { chemotherapy }\end{array}$ & $\begin{array}{l}\text { - Anatomic option for patients with liver predominant } \\
\text { disease } \\
\text { - Applicable since metastatic tumors are predominantly } \\
\text { supplied by the hepatic artery }\end{array}$ & $\begin{array}{l}\text { - Significantly improved PFS compared to } \\
\text { intravenous administration of chemotherapy } \\
\text { - No improvement in OS }\end{array}$ \\
\hline $\begin{array}{l}\text { Isolated hepatic perfusion } \\
\text { (IHP) }\end{array}$ & $\begin{array}{l}\text { - Delivers high doses of chemotherapy to the liver } \\
\text { with minimum systemic drug exposure } \\
\text { - Requires great skill and extracorporeal circulation } \\
\text { (limited use) }\end{array}$ & $\begin{array}{l}\text { - Radiological response in } 68 \% \text { of the } \\
\text { patients, with } 12 \% \text { having a complete } \\
\text { response } \\
\text { - Time to local progression was } 7 \text { months } \\
\text { - Median OS time up to } 24 \text { months }\end{array}$ \\
\hline $\begin{array}{l}\text { Percutaneous hepatic } \\
\text { perfusion (PHP) }\end{array}$ & $\begin{array}{l}\text { - Similar procedure to IHP } \\
\text { - Simpler to perform }\end{array}$ & $\begin{array}{l}\text { - Significantly improved median PFS } \\
\text { compared with best supportive care } \\
\text { - No improvement in OS }\end{array}$ \\
\hline Chemoembolization & $\begin{array}{l}\text { - Combines hepatic artery embolization with infusion } \\
\text { of chemotherapeutic agents }\end{array}$ & $\begin{array}{l}\text { - Patients with low tumor burden }(<20 \% \text { liver } \\
\text { involvement }) \text { - significantly improved OS } \\
\text { - Patients with high tumor burden }(<75 \% \\
\text { liver involvement ) - poor clinical response } \\
\text { and numerous major complications }\end{array}$ \\
\hline Immunoembolization & $\begin{array}{l}\text { - Use of GM-CFS } \\
\text { - Increase local mobilization and maturation of dendritic } \\
\text { cells to the tumor area after ischemic necrosis } \\
\text { of the tumor as a consequence of embolization }\end{array}$ & $\begin{array}{l}\text { - Median PFS shorter than in the group } \\
\text { with only embolization applied }\end{array}$ \\
\hline Radioembolization & $\begin{array}{l}\text { - Liver directed approach using yttrium-90 }\left({ }^{90} \mathrm{Y}\right) \\
\text { radiospheres } \\
\text { - Passes deep into tumor vessels } \\
\text { - Cannot enter the capillaries (sparing normal liver tissue } \\
\text { surrounding the tumor) }\end{array}$ & $\begin{array}{l}\text { - High response rates (up to } 62 \% \text { patient } \\
\text { with deficiency being small sample size) } \\
\text { - Median OS } 7 \text { to } 10 \text { months }\end{array}$ \\
\hline
\end{tabular}

OS - overall survival; DFS; PHP - percutaneous hepatic perfusion; PFS - progression free-survival; IHP - isolated hepatic perfusion; GM-CFS granulocytemacrophage-colony-stimulating factor

mary or metastatic cutaneous melanoma and genomic analysis of uveal melanoma is currently being undertaken $(8,45)$. The results of this analysis will potentially lead to the identification of new therapeutic targets and the development of new treatment methods for this rare subtype of melanoma (8). Currently, immunotherapy in uveal melanoma represents an area of active investigation (46). While inhibition with anti-programmed death protein-1 (anti-PD-1) and anti-cytotoxic Tlymphocyte-associated protein 4 (anti-CTLA-4) therapy has considerably altered the treatment approach to cutaneous melanoma, its effectiveness for uveal melanoma is still being assessed $(2,8,19,43,46)$.

\section{CONCLUSION}

Uveal melanoma is a rare but fatal disease whose biological behaviour is notably different from other forms of melanoma and therefore requires distinct treatment strategies. It is a complex malignancy requiring expertise in its management and despite all measures being taken has a high tendency for poor prognosis in the future. Even though no standardized treatment for metastatic uveal melanoma exists, considerable progress has been made to better our understanding of the biology of this melanoma type, leading to novel targeted therapy and immunotherapy approaches. Recent improvements in prognostic and diagnos- 
tic methods have not improved outcomes for uveal melanoma. The search for effective targeted therapy as well as effective immunotherapy for metastatic disease is still in progress. Additional studies are necessary to comprehend and enhance the efficacy of targeted therapy and immunotherapy in ocular melanoma. Decisions regarding treatment and the best clinical approach are imperative in order to provide individualized patient care.

\section{REFERENCES}

1. Chang AE, Karnell LH, Menck HR. The national cancer data base report on cutaneous and noncutaneous melanoma: a summary of 84,836 cases from the past decade. The american college of surgeons commission on cancer and the american cancer society. Cancer. 1998;83:1664-78.

2. Tarlan B, Kıratlı H. Uveal melanoma: current trends in diagnosis and management. Turk J Ophthalmol. 2016: Jun;46(3):123-37.

3. Yonekawa Y, Kim IK. Epidemiology and management of uveal melanoma.Hematol Oncol Clin North Am. 2012;26(6):1169-84. doi: 10.1016/j.hoc.2012.08.004.

4. Jovanović P, Mihajlović M, Đorđevic-Jocić J, Vlajković S, Cekić S, Stefanović V. Ocular melanoma: an overview of the current status. Int J Clin Exp Pathol. 2013; 6(7):1230-44.

5. Shields CL, Kaliki S, Furuta M, Mashayekhi A, Shields JA. Clinical spectrum and prognosis of uveal melanoma based on age at presentation in 8,033 cases. Retina. 2012;32:1363-72.

6. Virgili G, Gatta G, Ciccolallo L, Capocaccia R, Biggeri A, Crocetti E et al.. Eurocare working group. Incidence of uveal melanoma in Europe. Ophthalmology. 2007; 114:2309-15.

7. Singh AD, Turell ME, Topham AK. Uveal melanoma: trends in incidence, treatment, and survival. Ophthalmology. 2011;118:1881-5.

8. Blum ES, Yang J, Komatsubara KM, Carvajal RD. Clinical management of uveal and conjunctival melanoma. Oncology (Williston Park). 2016;30(1):29-43

9. Diener-West M, Reynolds SM, Agugliaro DJ, Caldwell $\mathrm{R}$, Cumming K, Earle JD, et al. Development of metastatic disease after enrollment in the COMS trials for treatment of choroidal melanoma: Collaborative ocular melanoma study group report No. 26. Arch Ophthalmol. 2005;123:1639-43.

10. Collaborative ocular melanoma study G. The COMS randomized trial of iodine 125 brachytherapy for choroidal melanoma: V. Twelve-year mortality rates and prognostic factors: COMS report No. 28. Arch Ophthalmol. 2006;124:1684-93.

11. Shields CL, Furuta M, Thangappan A, Nagori S, Mashayekhi A, Lally DR, et al. Metastasis of uveal mela- noma millimeter-by-millimeter in 8033 consecutive eyes. Arch Ophthalmol. 2009;127:989-98.

12. Kaliki S, Shields CL, Shields JA. Uveal melanoma: estimating prognosis. Indian J Ophthalmol. 2015;63 (2):93-102. doi: 10.4103/0301-4738.154367.

13. Kujala E, Mäkitie T, Kivelä T. Very long-term prognosis of patients with malignant uveal melanoma. Invest Ophthalmol Vis Sci. 2003;44:4651-9.

14. Buder K, Gesierich A, Gelbrich G, Goebeler M. Systemic treatment of metastatic uveal melanoma: Review of literature and future perspectives. Cancer Med. 2013;2:674-86.

15. Gomez D, Wetherill C, Cheong J, Jones L, Marshall E, Damato B, et al. The Liverpool uveal melanoma liver metastases pathway: Outcome following liver resection. J Surg Oncol. 2014;109:542-7.

16. Kapoor A, Beniwal V, Beniwal S, Mathur H, Kumar HS. Management of uveal tract melanoma: a comprehensive review. J Egypt Natl Canc Inst. 2016;28(2): 65-72. doi: 10.1016/j.jnci.2016.02.003

17. Chattopadhyay C, Kim DW, Gombos DS, Oba J, Qin Y, Williams MD, et al. Uveal melanoma: From diagnosis to treatment and the science in between. Cancer. 2016 Aug 1;122(15):2299-312. doi: 10.1002/cncr.29727.

18. Kaštelan S, Gverović Antunica A, Beketić Orešković L, Bakija I, Bogadi M. Uveal melanoma: clinical features and diagnostic procedures. Libri Oncol 2017; 45 (2-3): 81-8.

19. Kaliki S, Shields CL. Uveal melanoma: relatively rare but deadly cancer. Eye (Lond). 2017 Feb;31(2):241-57. doi: 10.1038/eye.2016.275.

20. Shields CL, Kels JG, Shields JA. Melanoma of the eye: revealing hidden secrets, one at a time. Clin Dermatol. 2015;33(2):183-96. doi: 10.1016/j.clindermatol.2014.10.010.

21. Kaštelan S, Dekaris I, Gabrić N. Uveal melanoma: diagnosis and therapeutic advancements. Libri Oncol 2001;29 (1):21-6.

22. Damato BE. Treatment selection for uveal melanoma. Dev Ophthalmol. 2012;49:16-26.

23. Shields CL, Furuta M, Berman EL, Zahler JD, Hoberman DM, Dinh DH, et al. Choroidal nevus transformation into melanoma: analysis of 2514 consecutive cases. Arch Ophthalmol. 2009;127:981-7.

24. Damato B. Progress in the management of patients with uveal melanoma. The 2012 Ashton Lecture. Eye (Lond). 2012;26:1157-72.

25. Nathan P, Cohen V, Coupland S, Curtis K, Damato B, Evans J, et al. Uveal melanoma UK national guidelines. Eur J Cancer. 2015;51:2404-12.

26. Wang Z, Nabhan M, Schild SE, Stafford SL, Petersen IA, Foote RL, et al. Charged particle radiation therapy for uveal melanoma: a systematic review and metaanalysis. Int J Radiat Oncol Biol Phys. 2013;86:18-26.

27. Gragoudas ES, Lane AM, Munzenrider J, Egan KM, Li W. Long-term risk of local failure after proton therapy 
for choroidal/ciliary body melanoma. Trans Am Ophthalmol Soc. 2002;100:43-8.

28. Zehetmayer M. Stereotactic photon beam irradiation of uveal melanoma. Dev Ophthalmol. 2012;49:58-65.

29. Mashayekhi A, Shields CL, Rishi P, Atalay HT, Pellegrini M, McLaughlin JP, et al. Primary transpupillary thermotherapy for choroidal melanoma in 391 cases: importance of risk factors in tumor control. Ophthalmology. 2015;122:600-9.

30. Yarovoy AA, Magaramov DA, Bulgakova ES. The comparison of ruthenium brachytherapy and simultaneous transpupillary thermotherapy of choroidal melanoma with brachytherapy alone. Brachytherapy. 2012;11:224-9.

31. Seregard S, Pelayes DE, Singh AD. Radiation therapy: posterior segment complications. Dev Ophthalmol. 2013;52:114-23

32. Hawkins BS; Collaborative Ocular Melanoma Study Group. The collaborative ocular melanoma study (COMS) randomized trial of pre-enucleation radiation of large choroidal melanoma: IV. Ten-year mortality findings and prognostic factors. COMS report No. 24. Am J Ophthalmol. 2004;138:936-51.

33. Bechrakis NE, Petousis V, Willerding G, Krause L, Wachtlin J, Stroux A, et al. Ten-year results of transscleral resection of large uveal melanomas: local tumour control and metastatic rate. $\mathrm{Br} \mathrm{J}$ Ophthalmol. 2010;94:460-6.

34. Collaborative ocular melanoma study group. Assessment of metastatic disease status at death in 435 patients with large choroidal melanoma in the Collaborative ocular melanoma study (COMS): COMS report No. 15. Arch Ophthalmol. 2001;119:670-6.

35. Singh AD, Borden EC. Metastatic uveal melanoma. Ophthalmol Clin North Am. 2005;18:143-50.

36. Eskelin S, Pyrhönen S, Summanen P, Prause JU, Kivelä T. Screening for metastatic malignant melanoma of the uvea revisited. Cancer. 1999;85:1151-9.

37. Feinstein EG, Marr BP, Winston CB, Abramson DH. Hepatic abnormalities identified on abdominal computed tomography at diagnosis of uveal melanoma. Arch Ophthalmol. 2010;128:319-23.
38. Onken MD, Worley LA, Dávila RM, Char DH, Harbour JW. Prognostic testing in uveal melanoma by transcriptomic profiling of fine needle biopsy specimens. J Mol Diagn. 2006;8:567-73.

39. Torres V, Triozzi P, Eng C, Tubbs R, Schoenfiled L, Crabb JW, et al. Circulating tumor cells in uveal melanoma. Future Oncol. 2011;7:101-9.

40. Diener-West M, Reynolds SM, Agugliaro DJ,Caldwell R, Cumming K, Earle JD, et al. Development of metastatic disease after enrolment in the COMS trials for treatment of choroidal melanoma: Collaborative Ocular Melanoma Study Group Report No. 26. Arch Ophthalmol. 2005;123:1639-43.

41. Furney SJ, Pedersen M, Gentien D, Dumont AG, Rapinat A, Desjardins L, et al. SF3B1 mutations are associated with alternative splicing in uveal melanoma. Cancer Discov. 2013;3:1122-9.

42. Niederkorn JY. Ocular immune privilege and ocular melanoma: parallel universes or immunological plagiarism? Front Immunol. 2012;3:148.

43. Agarwala SS, Eggermont AM, O’Day S, Zager JS. Metastatic melanoma to the liver: a contemporary and comprehensive review of surgical, systemic, and regional therapeutic options. Cancer. 2014;120:781-9.

44. Hendler K, Pe'er J, Kaiserman I, Baruch R, Kalickman $\mathrm{I}$, Barack V, et al. Trends in liver function tests: a comparison with serum tumor markers in metastatic uveal melanoma (part 2) Anticancer Res. 2011;31:351-357.

45. Cancer genome atlas network. Genomic classification of cutaneous melanoma. Cell. 2015;161:1681-96.

46. Kaštelan S, Gverović Antunica A, Beketić Orešković L, Salopek Rabatić J, Kasun B, Bakija I. Conjunctival melanoma - epidemiological trends and features. Pathol Oncol Res. 2018;. doi: 10.1007/s12253-018-0419-3.

Corresponding author: Snježana Kaštelan, Department of Ophthalmology, University Hospital Dubrava, Avenija Gojka Šuška 6, 10000 Zagreb, Croatia. e-mail:snjezanakastelan@yahoo.com 